Linguistics

RP300 Caribbean Studies

May - June 2005

A voice from heaven: could the study of glossolalia

benefit linguistic theory?

Introduction

In a broad sense, this discourse addresses the possible role of science in the exploration of supposed "supernatural" or spiritual phenomena. More profoundly, the study pursued here asks whether science itself, as generally conceived in Western society, may be enriched by such exploration. There is a suggestion here that conventional Western scientific enquiry, is the poorer for its traditional aversion toward enquiry beyond matters empirically reducible.

The precise area of scientific inquiry with which I am concerned is the field of Linguistics, defined as the study of the nature, structure, and variation of language, including phonetics, phonology, morphology, syntax, semantics, sociolinguistics, and pragmatics (The American Heritage(r) Dictionary of the English Language, Fourth Edition. Copyright (c) 2000). The supposed "supernatural" or spiritual phenomenon that I would subject to linguistic analysis is glossolalia, known more widely in Western society as the Christian practice of "speaking in tongues".

\title{
Glossolalia defined
}

The term glossolalia has its roots in the biblical occurrences of two Greek words "glossa", meaning "tongue" and "Ialein", to "babble" or 
"speak". Christians are divided over the precise meaning of this term. In some bible passages it seems to point to speech in an intelligible human language one has not learned (as in Acts 2:3-11) and in others it may refer to an unknown, possibly non-human (divine?) language (1Corinthians 14:2-27).

The term may even signify the mere utterance of sounds not distinguishable as speech, but nonetheless "meaningful" (Romans 8:26).

The Catholic Encyclopedia describes the uncertainty around the precise meaning of the term in this way:

Many explanations of this obscure charisma are proposed, but not one of them is free from objection. It may indeed be that there is some truth in all of them. St. Paul speaks of "kinds of tongues", which may imply that glossolalia manifested itself in many forms: e.g. in the form of foreign languages when required by circumstances, as with the Apostles; as a new language -- "a kind of speech distinctive of the spiritual life and distinguished from common speech, which to the exuberant feeling of the new faith appeared unsuitable for intercourse with God" (Weizsacker); or as the manifestation of the unspeakable groanings of the Spirit, asking for us, and causing us to cry, "Abba, Father" (Rom., viii, 15, 26).

We are not wholly dependent on Christians for a definition of glossolalia though, because this phenomenon is not exclusive to Christianity. In an article in the Journal of the American Scientific Affiliation entitled "An Ethnological Study of Glossolalia", the author George J. Jennings (March, 1968) observes that glossolalia is practiced among the following non-Christian religions: the Peyote cult among the North American Indians, the Haida Indians of the Pacific Northwest, Shamans in the Sudan, the Shango cult of the West Coast of Africa, the Shango cult in Trinidad, the Voodoo cult in Haiti, the Aborigines of 
South America and Australia, the aboriginal peoples of the subarctic regions of North America and Asia, the Shamans in Greenland, the Dyaks of Borneo, the Zor cult of Ethiopia, the Siberian shamans, the Chaco Indians of South America, the Curanderos of the Andes, the Kinka in the African Sudan, the Thonga shamans of Africa, and Tibetan monks.

In addition to this somewhat global distribution, another author, Jerome Rothenberg, a poet who also writes in the field of ethnopoetics (www.ubu.com/ethno/soundings/gloss.html) draws attention to the relation of glossolalia and similar phenomena to the work of poets and other "latter-day avantgardists".

Folkloric recoveries dating back to the nineteenth century, he says, began to reveal forms of languaging - as incantations, spells, etc. - that were later to influence and confirm experimental attempts to break through the limitations of conventional syntax and meaning.

According to Rothenberg, among the essential modernists, the Russian Futurist Velimir Khlebnikov made the most direct connection to the Christian practice of "tongues."

In A Night in Gallicia, he appropriated elements from a previously collected pair of wordless northern Russian incantations - a form of "magic words" ("the sacred language of paganism") that he also tied to the Orthodox use of Old Slavonic and the Catholic use of Latin, and languages like his own experimental zaum that were or had become, literally, "beyond understanding." Rothenberg also associates Khlebnikov with Hugo Ball who speaking about the first performance of his wordless poems said:

That was when I noticed that my voice, as if I had no choice, was taking on the cadence of a priestly lamentation, like the chanting of the mass 
in catholic churches east and west. I don't know how the idea came to me, but I started to chant the vowel sequences like church recitative. ... And then the lights went out and I was carried off the stage, my body bathed in sweat and like a magic bishop.

To these phenomena we could add the neologisms of Caribbean "speechifying" practice and the improvisational "scatting" that attended the emergence of Jazz music (Jaquith 1967).

In a study that features prominently here, Tongues in the Spiritual Baptist Faith: A Linguistic Analysis, by Hazel Ann Gibbs-De Peza (1996) the practice of glossolalia in her Trinidad based assembly is distinguished from that among Pentecostal Christians in particular.

She introduces a conversational dimension of glossolalia which has apparently been observed in the rituals of only one other movement, the Dancing Religion of Japan (May 1958, 86; cited on page 67 of De Peza).

Still, a significant portion of the material to be encountered in this discourse focuses on glossolalia as a characteristic of Pentecostal Christianity.

Hence, considerable attention will be given to the work of persons like William J Samarin, one of the more widely known researchers on the subject.

In his paper Making Sense of Glossolalic Nonsense (1974) Samarin argues,

Glossolalist metalinguistics must be examined, I say, in order to get a complete picture of Pentecostal beliefs and behavior. 
And another reason for doing so is that we can add to the information we have - far from adequate as it is - on naïve and prescientific notions about the nature of language and linguistic behavior

Samarin's subtle, scientific supremacist assumptions about "naïve and pre-scientific notions" aside (I return to that in due course), his point is valid.

From a Caribbean perspective, we have the added incentive of our demographic situation.

That is, the study of glossolalia - among Pentecostals or any other religious group - holds particular significance for Caribbean people because this phenomenon is typically associated with the lesser developed, economically dependent regions and peoples of the world.

That is, glossolalia is typically treated as an affliction of least economically empowered, lesser-educated (prescientific?) persons who turn to religion for refuge from life's complexities, hardships and injustices (also see Gibbs De Peza, 24).

Such so-called "Third World" persons, one may safely hold, constitute the overwhelming majority of the Caribbean population.

Actually, it has been suggested that the supposed founder of the modern Pentecostal movement, William J Seymour of the historic 1906 "Azusa Street revival" in California was originally from a Caribbean island, possibly Trinidad (American, Barbados-based evangelist Samuel Salters, in a 1999 sermon).

I am not suggesting that glossolalia is only to be found in third world countries or regions, like the Caribbean though. 
Indeed, a further incentive for the study of this phenomenon is its proliferation internationally from its American (or should that be Caribbean?) epicenter - a proliferation concurrent with the contemporary, worldwide expansion of Pentecostalism.

According to one source, Pentecostalism is not merely another denomination or Protestant sect but actually represents a fourth major strain of Christian ideology and practice, alongside Orthodoxy, Roman Catholicism and Protestantism (p. 646-647 The History of Christianity, 1990 Lion Publishing).

Caribbean people, living in the shadow cast by the "American eagle", so to speak, would do well to monitor the growth of this movement in this hemisphere.

The religious nature of Pentecostalism does not preclude influence by its adherents on the political, economic and other worldly realms in which they operate.

Actually, a number of studies done on glossolalia have focused primarily or significantly on Neo-Pentecostalism - a "newer" strain of glossolalist advocates and practitioners which is distinguished from its more publicized (or scandalized) antecedents by substantial patronage among middle-class and intellectual persons.

Buttressed by the numerical significance of their less educated and economically empowered counterparts, Neo-Pentecostal groups can exert significant socio-economic and political influence on their communities.

In the USA, evangelist Billy Graham has presided over the inauguration of more Presidents than any other minister in that country's history. He is not a glossolalist himself (according to well known Barbadian 
Pentecostal leader, Reverend Holmes Williams) but as an evangelical leader he is closely aligned with the Pentecostal movement. He shares their fundamentalist concept of Christianity.

In Jamaica, Barbados, Trinidad (three regional trend-setters) and other Caribbean territories, local chapters of organizations such as the Full-Gospel Businessmen's Fellowship International - a virtual

Pentecostal power-broker - exercise significant influence in both the commercial and political spheres.

A greater understanding of glossolalia could open the way to a better understanding of the "beliefs and behavior" (to use Samarin's words) of the tongues-speakers associated with such organizations - especially since they seem increasingly to be exerting influence on the decision making processes in Caribbean territories.

Constraints of time and space do not permit me to elaborate on the contribution of Pentecostals and other fundamentalists to the recent re-election of controversial United States President George Bush and the implications of his re-election for US-Caribbean relations.

In the Caribbean context then, it seems that the benefits of research into glossolalia may extend well beyond the purely academic or theoretical.

The only question, from my standpoint, would be what one considers the ultimate end of linguistic theorizing - the question of its proper contribution not only to its constituent linguists, but to the whole society.

So, I readily concur with Samarin's assessment that glossolalia must be examined. However, I "differ" with him in two very important respects. 
First, his objective to "get a complete picture" of Pentecostal beliefs and behavior.

This objective is almost certainly impossible for Pentecostalism in general and for glossolalia in particular.

As a Pentecostal glossolalist myself for about 22 years now (albeit a rather atypical specimen, especially in the last 18 years or so of my "Christian" walk), I can say with near certainty, that there are some dimensions of the glossolalia phenomenon that are beyond revealing.

It is a profoundly enigmatic phenomenon, not the least so because of its idiosyncratic and intuitive dimensions.

I am sure most Pentecostals, who readily admit that they do not know what they are saying (in the strictest sense of "knowing" ), when they speak in tongues, would attest to this.

Samarin, familiar with this view held by glossolalists and advocating an empathetic, sociolinguistic research methodology that respects their views, would probably agree.

He therefore may not have intended that his use of the word "complete" be taken too literally.

\section{Scientific Fundamentalism}

I nonetheless make a point of his use of the term because it smacks of the very scientific fundamentalism that I am challenging here: the very scientific prejudice and pretensions to certainty that has restricted research on glossolalia and kept it on the fringes of linguistic inquiry 
and theorizing.

The historical and philosophical underpinnings of this prejudice are explored, to some degree, in Paget Henry's Caliban's Reason, a treatise on Caribbean philosophical tradition.

Henry contrasts the linear, shallow totalizing, absolutist, autonomous and polarizing propensities of European philosophical formulations with the open, "intertextually embedded discursive practice" that distinguishes Afro-Caribbean philosophy.

He traces the latter's openness within an integrated, totalizing knowledge system to traditional African philosophy, with its emphasis on "spirit" and contrasts this with the dogmatic discourse of European philosophy - largely represented as an exercise in the legitimization of Europe's project of imperial expansion from the fifteenth century onward (pages 1-3).

For my own part, from a less nationalistic point of view (at least initially) I have been advocating a thought technology rooted in tentativeness from the early 1990's.

This is one of the fundamental themes of my first major treatment of religion, The Bible: Beauty and Terror Reconciled (TBBTR), as yet unpublished. A summary of this text is due to be published as part of York University's Caribbean Religions Project.

In TBBTR, I address the "propensity of the human mind to seek to establish some infallible, unquestionable, unchanging authority around which we may order our perception of reality and regulate our conduct."

I treat this propensity as a special kind of historical factor - a perpetual 
condition, to be precise - as distinct from an "event" that can be defined chronologically.

I emphasize too that unlike the "events" behind the absolutist, intimidating aspect of the Bible that I call its terror,

This condition is not peculiar to fundamentalist Christians, nor even to religious persons on the whole. This perfectionist inclination is evident even among the irreligious. It is part of the human condition.

Now, I would not presume to count Samarin, other linguists, and more generally other Western scientists among the "irreligious" (in fact I am mindful that one web source describes Samarin as a researcher with a Christian background) but their characteristic concern for a "complete picture" suggests the intellectual anxiety about certainty that I think presses humanity in general and scientists in particular toward dogmatic postulations.

Additionally, this mindset excites criticism (if not indignation) because it precipitates the subtle, possibly unconscious, scientific supremacist assumptions about "naïve and pre-scientific notions" that are typical of Western "secular" science.

Certainly in Samarin's case, notwithstanding his empathy with Pentecostal glossolalists, there is evidence of a patronizing presumptuousness in his research.

This will be more apparent as his research approach is compared to that of Michael T Motley - another study, along with Gibbs De Peza's, that is examined in significant detail here.

First though, I must state the second respect in which I differ with Samarin. This is more straightforward, and in fact, has been implied 
above. My primary concern is with glossolalia, not Pentecostalism nor any other Christian sect for that matter.

Exploration of the operation of glossolalia among non-Christian religious groups is, in my view, a very necessary part of acquiring as comprehensive a view of this phenomenon as possible.

Indeed, I regard the tendency of researchers to focus on Christians primarily or exclusively, as an unfortunate impediment to serious progress in this field.

Who is to say what might be discovered about language in its most elemental form, if, for example, a study of glossolalia alongside the ancient Hindu practice of Kundalini was pursued?

\section{The Toronto Blessing's tantric tinge}

A number of Christian polemicists (Antti Huima, 1996; Arnold G. Fruchtenbaum, 1997) seem to think that the latter practice shares several similarities with the Toronto Blessing experience - a spectacular variation on typical, contemporary Christian glossolalic expression.

This form of ecstatic expression involves the making or imitation of animal sounds. The phenomenon, without parallel in previous recorded church history, first came to the public's attention in 1994.

Of course, as is typical for fundamentalist Christian apologists, Huima and Fruchtenbaum judgmentally label both the Toronto Blessing and Kundalini demonic manifestations.

As a compromise response to such a charge, perhaps a case could be made for empirical research on glossolalia by Christians as a move toward understanding the devil's stratagems and thereby more 
effectively combating them.

A more "conventional" (the word seems rather incongruous here) and perhaps logical appeal could be made for research on the Toronto Blessing brand of glossolalic manifestation that taps into the field of Animal Language Research (ALR).

I pursue that angle in the conclusion below.

Whatever the motivation or angle pursued though, there is no question in this writer's mind that research on glossolalia can benefit linguistic theory significantly.

Research by Samarin, Gibbs De Peza, Motley and others has already demonstrated this.

What this conceptual study seeks to do is broaden the scope of such research by critiquing the epistemological constraints set (consciously or unconsciously) by previous researchers.

Primarily, I hope to impress upon the contemporary linguist, as I would upon all empiricists, the need to maintain a consciousness of the balance that must be sought between empirical certitude and an inquiring imperative, if the integrity of scientific pursuit is to be maintained.

It seems to me that the certainty with which some linguistic and other scientific postulates are being advanced today might have embarrassed that great apostle of empiricism, John Locke, himself.

In his Essay Concerning Human Understanding Locke seems to have taken - or at least intended - a rather more tentative, humble approach to the question of knowledge and certainty than he is typically credited 
with. He wrote,

If by this inquiry into the nature of human understanding, I can discover the powers thereof, how far they reach, to what things they are in any degree proportionate, and where they fail us (my emphasis); I suppose it may be of use to prevail with the busy mind to be more cautious in meddling with things exceeding its comprehension; to stop when it is at the utmost extent of its tether; and to sit down in a quiet ignorance of those things, which upon examination, are found to be beyond the reach of our capacities.

Chapter 1 : Methodology

\section{Explanatory note}

As a conceptual paper, this thesis largely offers analysis of others' research. This may seem inappropriate in the field of linguistics where original, empirical research employing a questionnaire, tape recordings and similar instruments - may be deemed more desirable.

Actually, a questionnaire was not only contemplated, but was broached, and the resulting material is appended.

However, a decision was made to persist in the mainly theoretical direction of this study. The basis of this decision lies, ultimately, in the 
author's assessment that

1. in the absence of clarity about a priori matters - premises being followed, facts assumed, and so on - the gathering and analysis of data would be flawed, and in turn, the conclusions reached and

2. the works of linguists who have conducted empirical research on glossolalia may be as useful sources of insight as the responses of practitioners of the phenomenon.

At any rate, a rather substantial account of my own glossolalic practice is included here.

The literature on glossolalia research surveyed reinforced the first point, as several researchers (for example, Gerrard and Gerrard, 1966: 65-67; De Peza, 1996: 186 et al) cited bias in foregoing studies, especially those treating glossolalia from a psychological perspective.

The methodology employed here, is therefore as follows:

Three studies, those of Samarin, Gibbs De Peza and Motley, are assessed with a view to determining the degree of epistemological openness with which researchers treat the subject of glossolalia.

The strengths and weaknesses of these studies as outgrowths or extensions of epistemological nuclei (perceived by this author) are highlighted and suggestions made for future studies.

The answer to the question of whether or not the study of glossolalia can benefit the discipline of linguistics is therefore represented as a matter of degree, reflected in the studies examined.

That is to say, the study of glossolalia can benefit linguistic study to the 
extent that such study is epistemologically sound.

Samarin's work, based on a sociolinguistic focus on the speech community has been singled out for particular attention precisely because it contrasts with the other two studies by rejecting the linguistic nature of glossolalia.

He focuses on the beliefs of glossolalists, ascertained through, among other things, a series of interviews and "...a wide reading of Pentecostal devotional, doctrinal, and apologetic literature."

This seems a largely useful, but fundamentally problematic approach, based on an arguably simplistic scientism that results in a rather restrictive assumption of what constitutes language.

Samarin's study has already been significantly engaged in my introduction. Actually, that study is not so much isolated for analysis as it stands more as a backdrop to the central question of my thesis, and is referenced at various intervals as the discussion unfolds.

Motley's and Gibbs De Peza's studies are the focal point of chapter two.

My own intuitions and observations as a practicing glossolalist are mainly treated in the conclusion of this study.

As already indicated, my preference is for a research approach that holds the secular empirical approach to analysis in tension with an approach that is more open-ended or speculative.

Following this epistemologically synthetic approach, I complement my subjective assessments with material on glossolalia from the field of psychology. 
I particularly highlight the views of Richard A. Hutch, Reader in Studies in Religion at the University of Queensland, Australia.

As indicated above, similar scientific material originating in the context of Ape Language Research (ALR) is also given attention.

Chapter 2: Motley and Gibbs De Peza's Studies

As my introduction indicates, I conducted a wide-ranging survey of the literature arising from previous research on glossolalia. This survey proved to be quite engaging. I found a diversity of views emanating from both "believers" and "non-believers", and contributing, overall, to a rather rounded, albeit enigmatic, picture of the phenomenon. Most provocative from an empirical point of view, were the findings of Michael T Motley and Hazel Ann Gibbs De Peza, the latter a Caribbean national, from Trinidad, and member of the Spiritual Baptist faith.

Motley, as indicated in personal correspondence in 2004, is of no particular religious persuasion.

Their projects standout because, of all the work surveyed, only theirs attributed structural linguistic value, and in De Peza's case even semantic value and a degree of something approaching "mutual intelligibility" to glossolalic speech.

\section{Motley's Study}

Motley's views are published under the title $A$ linguistic Analysis of Glossolalia: Evidence of Unique Psycholinguistic Processing

(Communication Quarterly, Vol. 30, No. 1, winter 1981). 
He performed a variety of linguistic analyses of glossolalia to determine both the extent to which it is language-like, and the extent to which it is linguistically dependent upon the glossolalist's native language. These questions were pursued within the context of a broader effort - typical of earlier glossolalia research - to confirm or disconfirm what Motley calls

"the intuitively supposed linguisticality of glossolalia...the overwhelming tendency for glossolalia to create an impression that a real language is being spoken."

He notes that when exposed to glossolalia, the uninitiated listener invariably evaluates the speech to be that of some true language. (18)

The results of Motley's study indicate, "that glossolalia is, in more ways than not, both language-like and unlike the speaker's native language".

He notes that these results are contrary both to earlier studies of glossolalia and to the predictions of then current psycholinguistic theory (18).

The results contrast, for example, with the findings of Samarin's study, as announced in the article cited above:

The careful, methodical, and intensive analysis of tongues led to an unequivocal but unstartling conclusion: every person with normal linguistic capabilities can produce glossolalia in a normal and not necessarily altered state of consciousness...Glossolalia is nothing more than the reduction of one's native language to just its phonological component, that too being simplified to its basic and frequently used sound and syllable units. (91) 
In D. J. Janes', "Glossolalia: The Gift of Gibberish," (1977), Samarin is reported to have written,

When the full apparatus of linguistic science comes to bear on glossolalia, this turns out to be only a facade of language - although at times a very good one indeed. For when we comprehend what language is, we must conclude that no glossa, no matter how well constructed, is a specimen of human language, because it is neither internally organized nor systematically related to the world man perceives.

This seems a rather severe assessment, particularly coming from one who, ostensibly, is seeking to promote an empathetic, sociolinguistic approach to the study of glossolalia.

At the very least, Samarin's insistence on systematic relatedness as a criteria of glossolalia's linguisticality overlooks the fundamental feature of arbitrariness in human language (Fromkin and Rodman, 1989).

What systematic relatedness is there in the conjugation of the English verb system that links the present, simple past and past participle forms of the irregular verb go ("go", "went" and "gone")?

However, Samarin's dismissal of glossolalia's essential linguistic nature is consistent with the decision he made in the course of his 1976 study that it would be unwise to study glossolalia "merely as a linguist, treating the recorded texts as if they were merely samples of ordinary language."

Samarin seems to justify his dismissal of the prospects of glossolalia for meaningful research at the formal, structural linguistic level, by focusing on its prospects as the object of sociolinguistic investigation. 
For him the most (or possibly the only) serious, fruitful study of the phenomenon required him to focus on the contextual data of glossolalic expression - that is, the "relationship between what the people believed, personally and idiosyncratically or in consensus, and what they spoke". Such a focus, he notes, is "axiomatic to sociolinguistics" (1976).

Yet this approach, especially when set against the backdrop of the fruitfulness of Motley's and Gibbs De Peza's structural analysis of glossolalic expression itself, seems excessively restrictive.

It also seems to posit a false dichotomy between the potential for glossolalia to be meaningful in its individual application, and its potential to be meaningful as a social phenomenon within the context of the communities that practice it.

Motley avoids this dichotomy. He does not pursue a sociolinguistic analysis of glossolalia but he does not dismiss the possible fruitfulness of such an endeavor either.

Fundamentally, he seems motivated by a more liberal view of language than Samarin.

At any rate, Motley labels Samarin's and other studies "unconvincing" (Campbell, 1965; Nida 1965; Jaquith, 1967; and Goodman, 1967 are also mentioned).

He charges that, "their analyses typically have been relatively superficial" and links this superficiality to reasoning which allows a single linguistically atypical characteristic to satisfy the criteria requirements for disconfirmation of glossolalia's true linguisticality.

He also charges that most earlier studies have examined very small 
samples of glossolalia and/or have employed a very limited range of linguistic analyses (18).

Ultimately, while he shares other researchers concern with the linguisticality of glossolalia, seeking to confirm or disconfirm its intuitively language-like impression, Motley has a more primary rationale: the notion, in his words, that "glossolalia may eventually provide a source of information about the psycholinguistic processing of natural language and speech."(18)

Unlike Samarin, who suggests that everybody with normal linguistic capabilities can produce glossolalia "in a normal and not necessarily altered state of consciousness", Motley proceeds on the assumption that non-glossolalists are incapable of producing "tongues" because speakers are normally bound by the psycholinguistic rules of their own natural language.

Citing Sherrill (1964) and Carlson (1967), he notes that this assumption has been tested and supported, as intuitive comparisons between genuine and faked glossolalia (the latter being attempts by non-glossolalists to imitate glossolalia or to invent a pseudo-language) have shown the faked glossolalia to be much less language-like and much more like the speakers' native language than genuine glossolalia (Samarin's concession, above, that while only a façade, as he sees it, glossolalia is at times "a very good one", may also be viewed as support for this position).

The implication of these comparisons, based on casual listening, is that glossolalia manifests "certain unique limits, capabilities and activities of language encoding processes" that, in Motley's view, make it worthy of special attention (19).

Recognizing the epistemic limitations of such intuitive assessments 
though, and hence, that the attention thus inspired may be premature, Motley's study addresses the need for empirical evidence of the uniqueness of glossolalia as indicated in the language-likeness of such speech and in the distinction of such speech from the native language of the speaker.

Accordingly, glossolalia samples from a 61-year-old male Pentecostal who had been speaking in tongues for 20 years were tape-recorded and then transcribed.

The subject was able upon request to produce two distinct varieties of glossolalia.

One variety was judged by competent linguists to sound very much like Spanish and the other remotely like Russian.

At intervals of seven to fourteen days, several recordings of about 15 minutes duration each were made. These amounted to slightly more than two hours of the Spanish-like variety (henceforth variety I) and one hour of the Russian-like variety (henceforth variety II).

Four 3-minute samples of variety I, and two 3-minute samples of variety II, representing ten percent of either variety, were extracted for analysis.

These selections were essentially random, the only restriction being that no two samples which were recorded within seven days of each other were selected.

Motley phonetically transcribed the six glossolalia samples, and an expert phonetician independently validated his transcriptions.

These transcriptions, along with phonemic transcriptions of Spanish 
and Russian (International Phonetic Association 1966), and Denes' phonology statistics on two samples of English (Denes, 1964), furnished the data for Motley's analysis.

Motley performed six kinds of phonological analysis, four kinds of morpheme analysis and a simple suprasegmental analysis on the data.

The limitation of these forms of analysis in the study of glossolalia where no semantic information is available was noted.

Nevertheless, it was felt that enough was known about phonological, morphological and suprasegmental universals, and about interlanguage trends to permit "a fairly thorough examination of the glossolalia samples' linguisticality.

A summary of some of the more salient features of Motley's findings follows:

1) A very complete language-like inventory of phone types for both varieties of glossolalia examined. This observation contradicts many earlier claims that glossolalia has a noticeably restricted phone inventory and that this is one of its basic non-linguistic characteristics (Carlson, 1967; Jaquith, 1967; Nida, 1965; Samarin, 1972). It however is in concert with De Peza's findings (see below).

2) In general the phone inventories for glossolalia and the speaker's native language (English) were quite dissimilar. Variety I and variety II comparison also revealed quite different distributions.

3) The degree of difference of relative phone frequencies between English and either glossolalia variety was in keeping with, if not greater than the degree of difference between the three natural languages English, Spanish and Russian. 
Motley notes that this is the first sign that glossolalic expression might not be influenced by the speaker's native language, again contrary to the implications of earlier studies (Jaquith, 1967; Samarin, 1972).

4) Correlation data comparing the glossolalia samples with the speaker's native language contradicted earlier claims of glossolalia's derivation from or dependence on the native language (Jaquith, 1567; Samarin, 1972).

The relative frequencies of phones for both varieties of glossolalia were less like those of English than like any other phone distribution with which they were compared $(r=.45, r=.32$ for variety $\mathrm{I} /$ English and variety II English respectively.

In other words, both variety I and II were more similar to either Spanish $(r=.71, r=.52$ for variety I and II respectively) or Russian $(r=.57, r=$ .49 for variety I and II respectively) than to English.

At the suprasegmental level, Motley found stress patterns within the word-like units for both varieties of glossolalia to be quite regular. Significantly again the rules followed were distinct from those of English.

Motley's study thus demonstrates that while the absence of semantic information imposes considerable limits on structural linguistic research into glossolalia, such research is nonetheless worthwhile.

Indeed, it could be argued that glossolalia is worth studying precisely because it may benefit linguistic theory by contributing to the science of semantics, broadening our concept of the phenomenon we call meaning. 
As Motley notes, linguistic structure is generally viewed as "an artifact of the semantic properties of language". In other words,

...without semantic information there is little or no inherent rationale for the structure systems (syntactic, morphological, phonological, intonational, etc.) of language or other speech behaviors. Randomness is acceptable if meaning is not expected, so structure is mandatory only if meaning transfer is expected.

However, Motley's glossolalia samples contained several examples of rather sophisticated structure within discourse which is presumed to be without semantic information and which at best only resembles language.

This, he says, leads to one of two choices: i) to regard glossolalia as having semantic content and therefore as a form of language - which appears to be Gibbs De Peza's choice or ii) to accept the relatively unheard of notion that linguistic structures may be the result of something other than semantic information - which appears to be Motley's preference.

He believes pursuit of the latter notion "should provide rich insights into the operation of psycholinguistic encoding and decoding processes in natural languages. He observes

Since the source of this structure is apparently not a simple borrowing or retaining of the existing structures within the glossolalist's native language, the glossolalia becomes especially perplexing.

Existing theory cannot easily account for language-like nonlanguage behaviors which exhibit either the suppression of the native language rules or the origination of and adherence to new rules, much less both. 
Apart from these issues, Motley also sees glossolalia research contributing to "the question of linguistic universals, on the assumption that the rules of various glossas might represent some sort of lowest-linguistic-common-denominators of all languages."

He also suggests examination of glossolalia for insights into language acquisition, at least because glossolalia challenges the classical learning approach to language acquisition, "since some speakers' first utterances of new glossolalia varieties appear to have their rules and structures intact."

Finally, Motley suggests psycholinguistic investigation of "the glossolalia state". Since glossolalists are able to manipulate linguistic structures in ways that non-glossolalists are not, he says, their implementation of a general cognitive state may be assumed.

He suggests determination of this state and then the examination of various kinds of psycholinguistic processing by inducing the state in non-glossolalist encoders and decoders. Among other things, says Motley, the limits of the encoding and decoding systems may be established (25) by such an exercise.

Gibbs De Peza's Study

Motley's study shares several features with Gibbs De Peza's. She set out to answer questions such as: are the glossolalic utterances of members of the Spiritual Baptist Faith 1) able to stand up under the tests of linguistic analysis - phonological, morphological, semantic, pragmatic? 2) intelligible and/or meaningful to the speakers/hearers? 3) acquired via normal second language acquisition processes? and 4) identifiable with known languages?

Gibbs De Peza was guided by certain basic concepts in communication, 
such as: i. that "certain communicative acts are involuntary, causing the communicator never to exercise total control of the communication event"(Prosser 1; foreshadowing the interactive, dyadic schema central to Shanker's ALR research that is mentioned below) ii. that "we are never in total control over a communication event, partly because it is part of a larger process, and partly because if we had total control over every situation, we would be Gods rather than men and woman (I must confess some difficulty seeing how the latter concern with divinity can be deemed a basic concept of communication) and iii. that the level of perception may be very small but at least a minimum amount of awareness must be present for interpersonal communication to take place (Prosser 3).

Gibbs De Peza's approach focuses on language as "not primarily a means of communication but a means of communion", as per Le Page (quoted in West 171).

Like Motley, Gibbs De Peza finds evidence of glossolalia's rule-governed character and the independence of its rules from those of the speaker's native language.

Part of her research yielding these findings entails an interesting employment of James R Jaquith's "scientifically more satisfying typology". This is based on the treatment of glossolalia "as communicative rather than as religious culture" ("Towards a Typology of Formal Communicative Behaviors: Glossolalia," Anthropological Linguistics, Vol 9. No. 8 Nov. 1967).

Using this typology Gibbs De Peza analyzes two glossolalic samples from two Spiritual Baptists, whereas Jaquith used one Pentecostal sample.

It may be recalled that in this discourse we first encountered Jaquith's 
work through a reference by Motley, who criticized Jaquith and others' studies for the insufficiency of the samples they used.

Gibbs De Peza's two samples, A and B, are compared with a third, C, which is derived from one of her subjects native Trinidadian Creole English speech, uttered in the same religious context as the others ( $A$ and B).

In contrast to Jaquith, Gibbs De Peza finds that in the glossolalic speech "vowel occurrence is not excessive, nor is vowel range limited. Repetitions are neither predictable or highly patterned."

Like Motley, she also finds that "the distribution pattern of the phones does not match the patterns observed in the normal speech of the speaker, neither are all the phonetic syllables observed or permissible there."

Gibbs De Peza summarizes,

The range of speech sounds and their patterns of occurrence are not identical and are different enough to postulate different languages, and similar enough...to postulate language status for all the utterances. The phonetic variation, the frequency of the segments and the phonotactics all attest to each of the three utterances qualifying in form as language. Since utterance three (C) is definitely language - a known language, Trinidadian English Creole - it lends credibility to the proposal of language status for $A$ and $B$. It also reveals an absence of patterns which can be termed rule-governed conversions of the native language of the speaker.

Throughout her thesis Gibbs De Peza is careful to distinguish Spiritual Baptists' glossolalia from that of Pentecostals: what Samarin in his supposed improvement on the aberrant pathology analysis of early 
glossolalia research defines as

A meaningless but phonologically structured utterance believed by the speaker to be a real language, but bearing no systematic resemblance to any language, living or dead (Samarin 197)

In the Spiritual Baptist context, says Gibbs De Peza, glossolalia is vocalization that does have describable communication value and does demonstrate many of the (desirable) characteristics of known languages.

In Chapter 6 Gibbs De Peza offers a broad contextual analysis, locating her group's glossolalia within a "cultural language" theoretical framework advanced by Maureen Warner-Lewis.

According to Warner-Lewis' theory, all the languages that circumscribe the linguistic history and setting (parameters) of a given society - in this case Trinidadian society - are part of that society's "language culture". Warner-Lewis believes that over time these languages yield fragments or patterns become a "notional fixity".

This would mean "leakage" and eventual fossilization (Selinker, 1972), of a sort, if I read Warner-Lewis (and Gibbs De Peza) correctly, of Yoruba, Hindi, Ibo, French, English and Spanish elements into the "collective unconscious" of Trinidadian English language users.

Warner-Lewis further posits that when a society composes new words, those words may derive from "prior little known or partially remembered phonological combinations along 'known' patterns in the linguistic community."

She ascribes to the society an ability, based on "informal cultural learning" to use certain distinctive features which are not remembered 
but known.

The richness of Trinidadian Creole is consequently attributed to past conditioning or acculturation which allows the members of the society to "study up something" from a deeper conscious level of linguistic ability (Warner-Lewis, personal interview, 1991).

Gibbs De Peza proposes that this "involuntary surfacing of items from the past" provides one possible source of the language of glossolalia. In support of this proposition, she cites Deese's observation that

We do not know how thought is transferred into speech, nor is there any way, given the limitations imposed by our current methods of investigation, that we are likely to know in the near future. All we know is that there is a vast intricate process beyond the reach of consciousness and largely beyond the reach of experimentation which produces speech melding of all of the aspects into a smoothly functioning whole.

She therefore compares lexical items from the various source languages with sequences in her glossolalia samples. These comparisons, undertaken by prominent Caribbean and international linguists, do not allow conclusive pronouncements, she notes, but she offers them as openings for future studies. The comparisons are of two classes of items: 1 ) items selected by native speakers and fluent speakers of other languages from their listening to recordings being played, and 2) items selected because of their similarity to items of other languages.

I offer what struck me as the more intriguing observations arising from both kinds of comparisons here. They are:

A Dr. Sharma, visiting Professor of Hindi, suggested:

[j ya devi] can be translated "victory to Goddess" 
Commenting on the context, he describes event DOS as "Some address to some unknown formation", event CUATRO as "some ritualistic fanfare like South Indian languages in style and rhythm".

2) Dr. Funso Aiyejina, Nigerian lecturer in African Literature, offered the following interpretations, citing possible African origins for some of the terms used:

[bia] - come (Igbo)

[daya] - one (Hausa)

[oyaya] - gaiety (Yoruba)

[aye yi] - this world (Yoruba)

Dr. Aiyejina noted sound patterns of East Nigeria, Hausa and Arabic with which he was familiar. He said "thought units" and sentence patterns were evident, suggesting the subject was "real language".

3) After hearing the tapes and reading the transcripts, Dr. Hubert Devonish, Reader in Linguistics, UWI, Mona, wrote,

"The tapes and transcripts suggest to me that we are probably dealing with a natural language or set of languages...Although the language(s) is/are clearly not Arabic, it shows some Islamic/Arabic influence... On page 3,1.7 we see [alamda] which strongly resembles the Arabic [ahamduah]. 1.5 [selekum seleki] is reminiscent in a way of Arabic [a salaam walaikum]. Strongest indication though is the constant appearance of the Arabic root [salam].

Devonish also identifies evidence of Bantu and Bhojpuri derivation in the material. Finally, he concludes that the glossolalic samples before 
him appear to be an agglutinating language - a language in which words are made up of a linear sequence of distinct morphemes and each component of meaning is represented by its own morpheme.

In her conclusion Gibbs De Peza reinforces Devonish's view, suggesting that Spiritual Baptist glossolalia may be "more of an agglutination from the language history of 'known' but 'forgotten' languages of the people than an 'improved' or 'highly patterned' performance....". Stressing the subjectivity of this interpretation, she urges those researching the phenomenon to bear in mind that in the African context, to which Spiritual Baptists trace their roots, "religion is part of life - an empirical experience, not an academic proposition."

Noam Chomsky's reference to the "use of language in ways that we can sometimes describe but hardly even begin to understand" is also cited.

This view supports Gibbs De Peza's, Motley's and my own point (see the reference to my "tentative thought technology" and Paget Henry's views on the distinctive spiritual ethos of Caribbean thought systems in the introduction) about the limitations of Western epistemic assumptions and scientific analysis in accounting for ostensibly non-Western, and to that extent, extra-empirical phenomena.

I say "ostensibly" because I am mindful that while the West is generally critical of extra-empirical science, it is not exempt from the influence or "incidence" of such science.

The extra-empirical rationalization of Christian thinker C.S. Lewis is well known, but how many know that one of the greatest leaders and "social engineers" of British society, John Wesley - the "Father of Methodism" - was not only a devout theist, but also, possibly a glossolalist too? 
Accounts of the strange "warming" of Wesley's heart on May 24th 1738 and his own description of the "Pentecost on New Year's Day" that he experienced six months later with his brother Charles, George Whitfield, Benjamin Ingham and other catalysts of Methodism (History of Christianity, 1990 p. 449, 454-456), bear close resemblance to both biblical accounts of the glossolalic "baptism of the spirit" and contemporary Pentecostal events.

Also, employing a cyclical pattern of degeneration and renewal - as I do in TBBTR - a link can very easily be made between the 18th century "Awakening" in which Wesley was prominent and the obscure Lollard movement that sprang up in England around the work of John Wycliffe in the 1350s.

The term "lollard" according to some authorities, derives from a Dutch term meaning "mumbler" or "mutterer". Other sources link it to Latin "Iolium", meaning, "tare", and hence "heretic" (THC p. 344).

The cyclical view of religious history, recommended by Robert Brow (Case-histories, pg. 34, The World's Religions, Lion Publishing) and others is not only in stark contrast with the Western linear view of history and progress and compatible with a non-Western, and particularly an African world view, but is also compatible with the theory of ancestral linguistic remission that Warner-Lewis introduces and Gibbs-De Peza offers as the source of glossolalic utterances.

On the issue of Western or European spirituality outside the Christian context, the same cyclical historical schema can be used to explain the contemporary resurgence among Europeans of elements of a spiritual outlook or worldview, often labeled "superstitious".

\section{Secular Scientism}


Indeed, these elements seem to have persisted among successive generations of Europeans from time immemorial. Some of these, including elements of Wicca and related "earth worship" systems, have achieved a degree of prominence today as part of the "New Age" movement.

Another noteworthy example of a departure from the secular scientism of the West, at an individual level, is Euro-American business astrologist and author Robert Gover's embrace of African spirituality, as detailed in his book "Voodoo Contra".

His and similar "testimonies" suggest that if the full benefit of research on glossolalia is to be achieved, care must be taken to ensure that it does not suffer from "reverse racist" analytic assumptions that preclude consideration of the operation of this and related phenomena among Europeans. I am not convinced Gibbs De Peza avoided this pitfall.

I must also note that I was intrigued by Gibbs De Peza's views on the role of human volition in glossolalic expression. She says Spiritual Baptists eschew "support for such practices (cited in Samarin and other researchers) as the teaching of tongues speaking, and the practice of it as an academic exercise in order to perfect it."

For Spiritual Baptists, she says, all teaching and practice are spiritual exercises and therefore must be instituted by the Holy Spirit and not by man's volition.

I think this claim reveals a rather conservative strain in Spiritual Baptist theology.

Ironically, while no doubt intended to authenticate the Spiritual Baptist experience relative to divine influence, it undermines the findings of 
several other researchers (Samarin, Virginia Hine [1967] and others) who stress the role of the human will in glossolalic expression in opposition to earlier claims that link the phenomenon to dissociation, a state of trance and other psychological aberrations that project a rather unflattering image of the human dimension of the experience.

Note too that the Spiritual Baptist experience represented by Gibbs De Peza, is in conflict with the testimony of at least one biblical writer who also supports conscious human involvement in tongues speaking.

Appealing for orderly employment of this spiritual gift, that writer asserts that "the spirits of the prophets are subject to the prophets" (1Corinthians 14:32).

The indication here, is that the individual's control of glossolalia is such that he or she can to some extent manage or manipulate this gift, much as the jazz singer manages or manipulates scatting.

This certainly is my own experience, upon which I elaborate in the next chapter.

Ultimately conceding the limitations posed by an absence of denotative meaning on her linguistic investigation, Gibbs De Peza hedges her position, so to speak, by noting that there is no definitive linguistic statement determining what features are necessary or sufficient characteristics for linguistic status. She says,

The inability to conclusively prove linguistic status does not necessarily refute such status and may only be indicative of a weakness reflective of the stage of development of available linguistic tools.

She proposes that based on the findings of her research, glossolalia as practiced within the Spiritual Baptist community displays "sufficient 
necessary features of human language to be classified as language".

Gibbs de Peza also proposes that perhaps with improved investigative tools and new research techniques the last frontier may be broken and the scientific proof necessary for its accreditation may be provided.

Summary

The foregoing suggests that there is merit in both an empirical and belief-based approach to inquiry into glossolalia. Both Motley's and Gibbs De Peza's approaches recommend the study of glossolalia as a fruitful object of structural linguistic research.

Both studies challenge the assertion of William J Samarin that glossolalia is non-linguistic and merely "symbolic" - a distinction which, as I have said before, turns on a rather restrictive "scientific" understanding, not only of language, but fundamentally, of science itself.

Motley's is arguably the more objective or open-ended of the studies, as he does not engage the question of the origin of glossolalia, divine or otherwise.

He is to be commended on this move, for such engagement would have required an at least modest treatment of theological and other a priori matters that were beyond the immediate scope of his study, and probably, his expertise.

Gibbs De Peza's approach is very promising, combining the basic structural linguistic analysis, characteristic of Motley's work, with the sociolinguistic exploration that has distinguished Samarin. 
On the other hand, her study is open to the charge of being compromised by the biases of an insider. Having said that though, it should be noted that she laments the absence of any study of glossolalia among Spiritual Baptists by outsiders, most of the research being concerned with Pentecostals.

Also Gibbs De Peza cannot be faulted too heavily for engaging the question of the divine or human origin of glossolalia, because total circumvention of this question would have rendered her study suspect, given the fact that she is a member of the Spiritual Baptist faith and a practicing glossolalists.

The authenticity and integrity of her scholarship must be assessed, in the final analysis, with due regard for the authenticity claimed for her and fellow Baptists' personal experience.

Such regard must of necessity allow that even where such matters of faith seem patent, they are often the most obscure.

While Gibbs De Peza is prepared to bring the full benefit of her training as a linguist to the study and illumination of this obscure aspect of her faith, she nonetheless respects and accepts the insolubility of some mysteries adhering thereto. We cannot do less than this, and it is virtually certain that we will fail, should we attempt more.

Chapter 3: My glossolalia

We now turn to a substantive treatment of my own intuitions and observations as a glossolalist. First, a background of my conversion to 
Christianity.

I was converted via the Pentecostal evangelical route in June $1982 . \quad$ I was in my final year of secondary school and I suppose, like most adolescents, at that age where one is emotionally and mentally ready to commit to a definitive view of the world.

Having been raised in a predominantly Christian society (at least nominally) and being of a somewhat conservative outlook at the time, I was predisposed to accept the message of the gospel.

In the more immediate circumstances, my conversion was a profoundly emotional experience, triggered in large measure by feelings of guilt.

I had just lied to a young man named Dennis, part of a visiting team of Christian youth from Pennsylvania who were doing evangelical work in Barbados and had held a service at my school.

Dennis had asked if I had accepted Jesus during the service. To avoid him "preaching" at me, I had said yes.

As I walked away from him though, I was overcome with a profound sense of guilt and shame over my dishonesty.

I went back to Dennis, confessed the lie and he led me in the "sinner's prayer" to "accept Jesus as my personal savior".

I was probably crying before we were done praying! It was an episode of self-confrontation such as I could never forget.

For the first time in my life I had an intimate awareness of my own unworthiness and Jesus' sacrifice for me. I must have wept, almost uncontrollably, for about thirty minutes - something that has taken on 
new significance for me in the light of Hutch's comparison of glossolalia with laughter and crying (below).

There was no "speaking in tongues" though. That followed as I gave myself unreservedly to the indoctrination of the Pentecostal assembly I joined.

I don't recall how I first heard of the practice, but I suppose my openness to it evolved out of the confidence I had in the authenticity of my own conversion and the kinship I felt with those around me who were glossolalists.

These circumstances contrast with the purely divine "propagation" or initiation of glossolalia as represented by Gibbs De Peza but correlate roughly with Samarin's findings.

That is, I view myself as having been "tutored" in the practice, to some extent.

Also with Samarin, John P. Kildahl and others, I would say that the regard I had for my tutors' authority or experience was a significant factor.

In his article Psychological Observations (one of a number of psychological studies featured in the very useful text "Speaking In Tongues", a guide to research on glossolalia edited by Watson E. Mills) Kildhal likens this willingness to be led to "hypnotizability".

He treats this as a form of ego regression where a person is "...trusting enough to turn himself rather fully over to someone else and to place one's momentary destiny in the hands of the other person."

My own tongue-speaking did not come about through direct 
intervention by another though - as by the ritualistic "laying on of hands" that is a Pentecostal practice. It was more the result of my own deliberate action.

I was sitting in one of my church's regular weekly services and was brought to a state of excitement by the preaching and/or personal reflections on what was being preached.

The fact that I do not recall the precise subject of the sermon suggests to me that my own ruminations may have been the main catalyst behind the event.

I recall bowing my head, praying earnestly and eventually, simply yielding my tongue to whatever "intuition" I was feeling.

In many ways the event was unspectacular and I recall occasionally wondering about its authenticity a brief while after.

As more time passed though, and as I persisted with these utterances I became more convinced that I had indeed received the gift of "tongues".

Also with time, and as some of Samarin's sources suggested, my tongue speaking apparently became more "sophisticated".

As I grew in confidence, I opened myself to utterances I intuitively sensed to be both more elaborate and precise.

I can only say intuitively because some of the utterances to which I am referring were (and are) not necessarily longer or more exotic sounding.

Indeed, I distinctly recall a phase during which I began to produce 
one-syllable sounds - somewhat similar in form and content perhaps to the holophrastic sounds of child language (Fromkin and Rodman 1993).

That is to say, I had the sense that each such utterance or sound was profoundly more meaningful than the chains of sound that I had up to then been producing.

Utterances took a more condensed and staccato form as previously unattained depths of emotion and insight were reached in my Christian experience and expression.

It was as though I had a deeper intuition or "revelation" of the inadequacy of language - even the "heavenly language" - as a medium of communication for our deepest thoughts.

From multi-syllabic "sentences" therefore, I moved to a stage in which the intuitions experienced seemed best represented by single-syllable offerings, punctuated by deliberate pauses.

It was a virtual interweaving of sound and silence.

Actually, this experience caused me to note the tragic developments in 2000 among the "Restoration of the Ten Commandments of God" sect in Uganda with keen interest.

Around 700 members of that sect were apparently murdered or committed suicide when their leaders' predictions of a millennial end of the world did not materialize.

I did not know if these cultists were glossolalists, but I wondered if their regard for silence was in any way similar to my own.

Members were reported to have practiced a strict communication 
policy that employed hand signals, severely restricting or excluding oral expression.

One of their leaders, Dominic Kataribabo, a defrocked, American trained Jesuit Priest, was described by a former friend as having returned from America "...quieter, not as exuberant as before he went."

Kataribabo was also described as seeming "more deliberate in his talking and thinking."

I have sometimes wondered if through my glossolalia I have given myself too unreservedly to something I don't fully understand: if, in Kildhal's terms, I have become hypnotizable.

However, I don't worry too much about that because from the outset, my experience of glossolalia was marked by conscious, deliberate effort: in my case the spirit of the prophet is indeed subject to the prophet.

Following Kildahl (p. 358), I could easily associate what I do with the "turkey talk" employed in acting classes. Using this technique, actors and actresses are able to speak a language which sounds like glossolalia (Motley would probably disagree) but is simply, in Kildhal's words, "an exercise in the free flow of emotion and verbal expression without intellectual content."

I should also add that from the outset of my Christian journey, I have sought to balance my faith with a degree of skepticism.

\section{Epistemological elasticity - holding things in tension}


This epistemological holding of things in tension is the fundamental, ideological "infrastructure" that houses my tongues speaking.

I would not suggest that my experience is typical though - no more than I would suggest that it is unique.

Also, while stressing this human volitional dimension of my glossolalia, I must also note that with the passage of time, another feature of it has developed, more or less spontaneously: this is the occurrence of "spasms", which persist to this day.

The "spasms" are difficult to describe. Essentially though, they are physical phenomena, which sometimes cause me to throw my head back, and/or flex my arms uncontrollably.

These spasms can occur anywhere, anytime, the only apparent condition being my contemplation of some 'truth' or keen sense of a 'point' made or revealed.

It may be nothing more than a contemplation of the authenticity of the said tongue-speaking!

This unconscious, relatively "uncontrollable" dimension of my tongues largely serves to convince me of the authenticity of the experience.

Still, I am not dismissive of the initiative I exercised at the outset of this experience or the relative control that I exercise over my glossolalia today.

Indeed I view the voluntary and spontaneous dimensions of the experience as complementary elements of the one phenomenon.

Perhaps the notion of a "divine concursus" proffered by theologian J. I. 
Packer as an explanation of the notion of "inspiration" behind the authorship and transmission of the Bible could be employed in this context.

This notion suggests God's operation in and with human beings in the exercise of their own natural powers (New Bible Commentary, Eerdman).

I have found considerable support for this super-natural (rather than supernatural) interpretation of my glossolalic experience in Richard Hutch's The Personal Ritual of Glossolalia, another psychological treatment of glossolalia that appears in Mills' text.

While not unproblematic, his study provides useful biological insights that can be easily reconciled with what I experience intuitively. I elaborate on his study in my conclusion.

\section{Conclusion}

My Glossolalia and Hutch's Paradigm

Hutch's paradigm of glossolalic experience is proposed as an improvement on three others represented by Kildhal, Goodman and Samarin, whose work he views as arising from methodological assumptions that shape their respective disciplines (psychology, anthropology and sociology).

These assumptions are classified, the suggestion being that psychologists, anthropologists and sociologists believe glossolalia functions in a threefold manner: as aberrant behavior, as extraordinary behavior, and as anomalous behavior.

Hutch gives examples of these positions, presents their shortcomings 
and offers his own methodological paradigm, focused on the personal religious experience, as a corrective.

He thus employs a somewhat synthetic conceptual approach, similar to my own. A brief overview of how he goes about this follows.

Hutch notes that the aberrant behavior paradigm, represented by Kildahl (1972) and others, essentially treats glossolalia in the context of psychopathology and that the bulk of these studies have tended to view speaking in tongues negatively, as a form of ego regression.

As indicated above Kildahl's, is one of the more positive treatments, viewing such regression as a temporary, therapeutic development, pursued in the service of ego growth.

In the extraordinary paradigm, represented mainly by Goodman (1972) the focus shifts from intrapsychic to social dynamics, the wholesome function of tongues being viewed as a consequence of its normalization by the community of practitioners.

Also, and significantly, this paradigm does not presume that ego regression is fundamental to the glossolalic experience: rather, as my own experience suggests, the speaker is deemed to be exercising full ego-control.

To resolve the difficulty posed by this notion Hutch resorts to explanations from studies of the nature of human consciousness, exploring subcortical and cortical dynamics in the processing of experience.

He says,

...all experience has been found to be "state-bound" (Tart, 1973, 1975, 
1975a; Ornstein, 1972). This means that consciousness, including what researchers labouring under the assumptions of the aberrant behaviour paradigm would call the "unconscious," arises from two things: First, subcortical arousal; either an increase ("ecstasy") or a decrease ("tranquility") in the sensory and electrical chemical stimulation of one's sympathetic nervous system and overall psychic state is necessary. Second, also required is cortical (cognitive) interpretation of that arousal, which involves various degrees of conceptual and abstract thought under the control of prevailing cultural forms and symbols and their variations. Experience is essentially symbolic and necessarily state-bound - it can be invoked in its specific instances only by inducing a particular level of arousal, or by presenting some symbol of its interpretation such as an image, a melody, or a taste.

The coupling together of arousal levels and interpretations articulates various levels of human consciousness (Fischer, 1971, 1975; Goodwin, 1969, p 386.

Those working with the extraordinary behavior paradigm assume that tongue-speakers control their ego- state by deliberately inducing levels of subcortical arousal, and by self-consciously employing formal cortical (social and cultural) interpretations of arousal levels to "expand" as it were "consciousness".

There are echoes of Gover here.

As for the anomalous paradigm, represented by Samarin (1972), Hutch says here language structure is emphasized, as tongues is assessed in a similarly naturalistic manner.

Again there is no question of ego regression, in the main. Tongues is treated as a fundamentally nonlinguistic, chiefly symbolic religious 
activity undertaken with full awareness by practitioners in the service of their religious goals.

Strangely though, from my point of view, Hutch seems untroubled by Samarin's arguably "anomalous", and at least ambiguous, use of the term "linguistic".

He notes that Samarin "bluntly" states that glossolalia "is fundamentally not language" (Samarin, 1972: 227) and apparently has no difficulty reconciling this position with Samarin's other view that glossolalia is "a linguistic symbol of the sacred...a precarious possession, a divine gift" (Samarin, 1972: 221).

The absence of any conceptual contradiction seems to lay, for Hutch, in his view that unlike Goodman, "...Samarin considers symbols in themselves, not merely as an expression of an altered awareness."

Hutch advises that a distinction be made between "the view of the non-believer that tongues are not miraculous, just anomalous in regard to ordinary speech," (which seems to be Samarin's view) and "the believer's staunch conviction and felt sense that God is present in such utterances." The bridge between these two positions, according to Hutch, is "to say that tongue-speaking symbolizes the presence of the sacred, God". Two major functions are thereby performed, he continues:

First, glossolalia functions linguistically, with no mystery, to distinguish the sacred from the profane. Second, glossolalia activates the affective existential dimension of religion in the individual life.

Hutch then, seems influenced to some degree by the same impractical concern to "get a complete picture" as that expressed by Samarin (see my introduction). 
The difficulty of the element of "mystery" is thus removed from his analysis (like Samarin's), by positing what in my view, is an unduly, excessively rigid distinction (bordering on a dichotomy) between how glossolalia functions, and what it is.

A more useful and salutary approach, I think, is indicated by Motley's analysis, which accepts the mystery of glossolalia, at the linguistic level, quite apart from any attribution or consideration of a divine origin or nature.

We have yet though, to look at Hutch's own paradigm, proposed, with some justification, as an improvement on the others represented in the foregoing.

Hutch's paradigm incorporates some elements of the extraordinary and anomalous paradigms but represents glossolalia as ritual behavior which aims, first, to amalgamate the sounds of crying and laughing symbols of hurt and joy in life - and second, thereby point to conditions of existence, particularly to death and birth in life.

Using a term borrowed from Goodman, Hutch says glossolalia represents a "placing", that is, a repetitive activity aimed at "accentuating and directing attention to the intransigent, existential parameters of ordinary, everyday life and responsibilities." Hutch also invokes the views of comparative religion and social sciences scholar John Bowker (p.390) who, in his work on religion as a system of communication within the process of human evolutionary development (1978: 15-16) suggests that what is eventually labeled religion in all cultures

\footnotetext{
"appears as a part and consequence of the general attempts of men to scan their environment, to discern the limitations which circumscribe a
} 
projected action (or the continuity of their life-way as such), and to engage whatever resources they accept (whether consciously or not) as appropriate to the penetration or understanding of any particular compound or limitation".

Hutch then equates placings with "personal processes of scanning" (390), a self-conscious activity of paying attention to the fragility of life and thereby gaining personal power in the form of "new meaning". He says such "embedded meanings" are not only largely intuitive and presemantic (and almost preverbal), but they also give rise to abstract, cognitive thought in other contexts.

Glossolalia by Hutch's interpretation is therefore

...one technique that mediates or builds a bridge between subcortical arousal and cortical (cognitive) interpretation. It takes the statebound limitations of various levels of arousal and seeks (and finds) a way through them, toward a resolution of human intransigencies, at least for a moment.

Elaborating this phenomenon in the context of cognitive psychology, Hutch goes on to represent glossolalic placings as ritualistic, self-induced "conditions of dysfunction", breaking down or setting aside the natural processes of "habituation" or "automization" that protect human beings from perceptual (information) overload, and facilitate the constancy of every-day awareness necessary for basic human survival - both as an organism and as a personality (392).

According to Hutch then, speaking in tongues results in "alternate or 'deautomatized' modes of attention", whose stimulus processing, 
though less efficient from a biological point of view, may nevertheless permit the experience of aspects of the real world formerly ignored or selectively blocked-out. The "key", says he, is how the brain processes sensory input.

Finally, having considered how humans relate to our phenomenal world through the personal ritualization of experience, Hutch points out the similarity between the sounds of glossolalia and "other very evident presemantic (and pre-verbal) human sounds".

Referring specifically to the sounds of crying and laughing, Hutch postulates that glossolalic utterances are amalgamations of these sounds.

Treating laughing and crying as "essential liminal aspects intrinsic to the ritualization of all human experience", he notes that they serve to demarcate where language proper ends and non-linguistic utterances begin, and represents them as "strategic psychological responses by which an alteration and juxtaposition of a new world of meaning is made to stand over and against a more rigidly structured, cognitively organized and controlled world of meaning".

Accordingly, glossolalia is seen as activating "a range of possible painful or pleasant conditions of dysfunction which point to the existential meanings conditioned by human biology and actively rehearsed in terms of ritualized sounds, which are their symbols."

Hutch's analysis resonates with the writer's own experience in significant ways. As repeatedly stated before, I can certainly attest to the deliberateness of the experience.

More than this though, I also can relate to the notion of abandonment (breaking down or setting aside) of habituated or automatized 
processes of perception - at least, I have an intuitive sense that this is what I do when I speak in tongues.

Chiefly, I have come to view the experience as one of calculated risk-taking - a cognitive and affective movement away from the familiar into the unknown; an ideolectal risk-taking movement, analogous to the risk-taking represented as a feature of second language acquisition (Brown 1994, et al).

Motley's intuitions about the implications of research on glossolalia for understanding $L 2$ acquisition are thus supported by my experience.

Also, for me, glossolalia does not only involve self-edification (1Corinthians 14:4); it is also self-exploration such as Hutch identifies when he speaks of the self-reflecting on that part of itself - its antiquity or origin-ality - that is an expression of God's image and essence.

It is the self looking beyond the most familiar of itself to the "unknown", or better, "little known" or less familiar "other" that has generated it.

There is a natural correlation here with the "ancestral" aspect of tongues, as represented by Gibbs De Peza.

Glossolalia may be viewed as an effort of the self to recover and reconnect with its most distant beginnings (ancestors), or in religious terms, its most eternal existence (God, divinity).

\section{Tongues may be viewed as an expression of the soul rekindling the warmth of the original, unquenchable "flame" by which it was ignited and illuminated.}

It can then be viewed as expressive or verbal ("I believed therefore 
have I spoken" 2Corinthians 4:13) reconciliation of the superficially disparate but fundamentally unified phenomenon that is human language - or in more strictly linguistic, scientific terms (and as indicated by Motley), the phenomena called "language universals".

Actually, I have engaged this phenomenon before in TBBTR where, treating the matter from a theological and ethical perspective, I speak of "the universal testimony of conscience" (chapter 5).

There conscience is discussed both from the perspective of secular authorities and biblical evidence.

Ultimately, the ambiguity of conscience (approximately, not exactly, a "consequence" of the biologically deficient stimulus processing of which Hutch speaks) is treated as an inevitable, inescapable and instructive reality.

I suppose my own deep sense of the inadequacy of the human organism - such "intransigence" (if I accurately understand Hutch's use of this term) as the fact of birth and death in life - predisposed me to endure the hazards of 'deautomatized' perception that glossolalia induces.

As noted in TBBTR, Jung's representation of the workings of the "collective unconscious" offers a comparable perspective. Our focus is the realm of rendezvous of the individual and collective souls, in which the "ego growth" of which Kildhal writes (above) is facilitated.

Caribbean poets Edward Kamau Brathwaite and Derek Walcott and novelists Wilson Harris and V.S Naipaul (and philosopher CLR James), as represented in Viola Davis' “The Creative Use of Schizophrenia In Caribbean Writing", may be viewed as offering a similarly related paradigm 
Hutch's paradigm is compelling to the extent that though largely secular in its terms of reference, it explicates this "religious" phenomenon with some accuracy.

I differ with him though, in his assessment that the religious functions of tongue-speaking "are quite different from either psychological or sociocultural functions", the respective touchstones of the aberrant and extraordinary behavior paradigms.

A similar distinction of religious function from, in his words, "the strict linguistic emphasis" of the anomalous behavior paradigm, is similarly problematic for me.

My problem lies in the solely or narrowly secular, dated (post "enlightenment") meanings assigned the terms used.

"Psychological" considerations, if they are to be true to their historical-linguistic origins, as studies of the soul (Greek psyche) must overlap - if not become fused - with religious concerns!

And what is sociology, with all due respect to French philosopher Isidore Auguste Comte who coined the term in 1830, if not the study of psyche in its plural formations and dynamics?

What is Linguistics, if not the study of "the word that became (and becomes) flesh"?

If psychological, sociological and linguistic paradigms are "quite different" it is because we through academic ignorance, avarice and/or imperialism have made them so.

The fundamental problem, is the epistemological fossilization of 
knowledge that has characterized the scientific age.

The Hegelian instance of such schizophrenic scientism, with its attendant racial profiling of "ways of knowing" is probably a good place to begin an engagement of these issues.

The typically Western dichotomization of human experience and science into "religious" and "secular" categories, with the former stressing a notion of "certainty" is symptomatic of this problem.

Religious appeals to "faith" also can lead to the same dogmatism. As I argue in my essay Informed Faith, the natural and supernatural should not be viewed as anti-thetical, but rather, as differing points of a continuum of experience.

Summary

Space does not allow an exhaustive pursuit of this point here, but early in my formal study of linguistics, I was struck by the number of correspondences between the dynamics of linguistic and religious phenomena.

The correspondence between the phenomena of linguistic "standardization" and religious "canonization", both exerting an "automatizing" influence on human experience, is among the most obvious.

The study of glossolalia, from an epistemologically synthetic (rather 
than schizophrenic) perspective, could benefit linguistic theorizing by making these and other correspondences explicit.

Among other things, future research into glossolalia should consider the area of Animal Language Research, a matter merely broached here in relation to the charismatic Toronto Blessing phenomenon.

I was struck, from the very outset of my studies in linguistics, by the propensity of some theorists engaged in the discipline to make, what in my view, are ultimately insupportable claims of certainty.

The claim, for example, that only human beings possess language (Fromkin and Rodman, 1993, et al).

Even when qualified by reference to qualitative distinctions between the communicative faculties in humans and animals, the claim seems to exceed the limits of what we can claim to know with certainty.

In the same text, the authors note that the debate on the origin of language is open and ongoing, but seem to have closed their minds to the possibility that the two issues - that of animal language and that concerning the origin of human language may be related.

They seem to accept the Chomsky position (as it would appear does Samarin and most other linguists) cited by journalist George Johnson in his article "Chimp Talk Debate: Is It Really Language?" that "special neural circuitry needed for language evolved after man's ancestors split from those of the chimps millions of years ago" (New York Times, June 6th 1995).

There is however, the alternate view identified by Johnson that "...there is not an unbridgeable divide between humans and the rest of the animal kingdom, as orthodox linguists believe, but rather a gradation of 
linguistic skills."

This view is held by Dr. Sue Savage Rumbaugh, of the Language Research Center at Georgia State University in Atlanta, Dr. Stuart Shanker, a philosopher at York University in Toronto, and Dr. Talbot Taylor, a linguist at the College of William and Mary in Virginia.

Their book "Apes, Language and the Human Mind: Philosophical Primatology" (Routledge, 1995), featured prominently in Johnson's article.

It is perhaps significant though, that Samarin's, De Peza's and other linguists' focus on the social dimensions of glossolalic communication is matched by a somewhat similar focus among Ape Language Research (ALR) specialists - particularly their dyadic analysis.

Future research should also look for correspondences or connections between glossolalia and humans' melodic sense.

Hutch notes that "controlled situations like meditating, rhythmic chanting and drum-beating" may also create conditions of dysfunction approximating those induced in or by glossolalic utterance (the uncertainty here is mine).

This would suggest that the similarity of Jazz scatting and glossolalia is not incidental, but systemic.

One Trinidadian academic Alicia Saldhena is currently exploring the link between Jazz and Calypso as represented in the life and work of a compatriot pioneer in both media.

Could there be some connection here with the suggestion that William J Seymour of the historic 1906 Pentecostal "Azusa Street revival" was 
originally from a Caribbean island, possibly Trinidad (Introduction).

Of course, this may all seem highly speculative. However, as stated earlier, I believe an inquiring imperative is critical to authentic empiricism. This is how we avoid the epistemological fossilizations mentioned earlier.

Finally, I will close with the words of Carl Jung, one who bridges the empirical-faith divide. In his landmark book Man and his Symbols, Jung cautions

Modern man does not understand how much his "rationalism" (which has destroyed his capacity to respond to numinous symbols and ideas) has put him at the mercy of the psychic "underworld". He has freed himself from "superstition" (or so he believes), but in the process he has lost his spiritual values to a positively dangerous degree. His moral and spiritual tradition has disintegrated, and he is now paying the price for this break-up in worldwide disorientation and dissociation.

\section{Bibliography}

Jaquith James R, "Towards a Typology of Formal Communicative Behaviors: Glossolalia," Anthropological Linguistics, Vol 9. No. 8 Nov. 1967.

Paget Henry, Caliban's Reason, 2000, Routledge, New York Michael S Gazzaniga, Cognitive Neuroscience, 2000, Blackwell Publishers, Oxford 
Blakely, Thomas D; Van Beek, E A Walter, Thomson, Dennis L - Religion In Africa, 1994, Heinemann, New Hampshire Jay Timothy - Why We Curse, 2000, John Benjamin Publishing, Amsterdam

Saporta, Saul - Psycholinguistics - a book of readings, 1961, Holt, Rinehart and Winston Inc, USA 